\title{
22@ and the Innovation District in Barcelona and Montreal: A Process of Clustering Development between Urban Regeneration and Economic Competitiveness
}

\author{
Angelo Battaglia and Diane-Gabrielle Tremblay \\ Télé-université, Université du Québec à Montréal, 100 Sherbrooke West, Montréal, QC, Canada H2X 3P2 \\ Correspondence should be addressed to Diane-Gabrielle Tremblay, dgtrembl@teluq.ca
}

Received 11 June 2011; Revised 9 November 2011; Accepted 28 November 2011

Academic Editor: Ben Derudder

Copyright (C) 2011 A. Battaglia and D.-G. Tremblay. This is an open access article distributed under the Creative Commons Attribution License, which permits unrestricted use, distribution, and reproduction in any medium, provided the original work is properly cited.

This paper analyzes the governance strategy of the 22@ District in Barcelona in order to assess the factors that explain its success and could support the economic reconversion of Montreal's future Innovation District (ID), as well as that of other cities. We examine the case of the 22@ District as a former industrial neighbourhood seen as a "model" of urban regeneration and economic revitalization. Our assumption is that the world's major cities are going through a phase based on the reorganization of central urban areas. Our article evaluates the main factors of urban regeneration in the 22@—district of innovation and it identifies elements of best practices in terms of governance which can be constructive for the "Quartier de l'Innovation" in Montreal and similar projects of other cities. The paper highlights the role of decision makers concerning the process of governance of 22@ and its historic changes, and insists on the the role of socioeconomic actors and territorial factors that could support the level of integration and implementation of Montreal@ID. Our paper highlights the importance of the integration process based on socioterritorial innovations characterizing the Catalan context of 22@ as well as the Innovation District, something useful for other similar initiatives.

\section{Introduction}

The primary purpose of this paper is to analyze the governance strategy of the 22@ District in Barcelona in order to assess the factors that explain its success and possibly support the economic reconversion process of Montreal's future Innovation District (ID), as well as that of other cities. Through a comparative analysis, we examine the case of the 22@ District as a former industrial neighbourhood seen as a "model" of urban regeneration and economic revitalization. This study on territorial and socioeconomic development is based on the assumption that the world's major cities are going through a phase based on the reorganization of central urban areas. This is a process that can be explained by the polarization of advanced economic activities in the city's core following the emergence of new sectors of the post-Fordist economy [1-3]. This research evaluates the main factors of urban regeneration in the 22@_district of innovation and it identifies elements of best practices in terms of governance which can be constructive for the "Quartier de l'Innovation" in Montreal and similar projects of other cities.

The first part of the analysis highlights the role of decision makers concerning the process of governance of 22@ and its historic changes. The second part focuses on the socioeconomic actors and territorial factors that could support the level of integration and implementation of Montreal@ID. In fact, this paper highlights the importance of the integration process based on socio-territorial innovations characterizing the Catalan context of 22@ as well as the Innovation District. Consequently, observing the 22@, some pertinent questions can be formulated in regards with the integration process which appears to be based on two key assets. The first one is the spatial integration which supports the concentration of firms and institutions in terms of closer geographical proximity. The second one is the relational and institutional 
integration that fosters and enhances the partnerships and exchanges between universities/R\&D and firms. Therefore, our analysis intends to verify whether the integration process in the 22@ has been implemented with the two key assets mentioned above (spatial and institutional/relational) or not and to verify which kind of lessons Barcelona could provide to Montreal in terms of organizational process. This study follows a twofold perspective.

The first one highlights the role of local actors (public and private) in increasing the economic clustering process regarding the levels of proximity and the nature of integration. The second one aims at supporting a system of cultural values, codes, reflections, and rules among local stakeholders which are fundamental in developing common spaces of governance and shared strategies of development. The study can determine if the 22@_Innovation Districtcan represent a development model of reference based on a multiclustering pole for the Innovation District (ID), polarized around the Multimedia City and the ETS [4-6]. The relation between territory and innovation generates an innovative approach based on the close linkages among university/research environments and high-tech/creative enterprises. This connection could represent a new territorial dimension of innovation as well as the advancement from the typical model of linear technopole of functional theory to the innovation cluster of relational proximity-based theory [7]. In our view, while it is interesting to use in the analysis, the technopole model is somewhat limited and this is why we also use a model which includes more relational and interaction dimensions. The relational proximity approach will thus constitute our preferred framework of analysis since we intend to show that the Innovation District could be considered as an emerging innovation cluster that is developing through a "new model" of clustering and technopolitan approach which is a mix between the linear and functional technopole approach and the relational-based approach. We can thus define it as a hybrid model of development, as the case of 22@ appears to be in Barcelona, because it maintains the functional features of the typical urban technopole and, as well, it provides new forms of organization based on a mutual and interactive synergy with local stakeholders and social communities embedded in the neighborhood. In fact, this hybrid model is formed by a concentration of hightechnology industries and scientific institutions (such as the 22@), but it has a tendency to provide new institutional and creative interactions with different local players in terms of relations and final targets. This is an important aspect that highlights how the social communities and endogenous local actors in Montreal are more involved in the inclusive process of socio-economic regeneration and territorial change.

This research was conducted using an interdisciplinary systemic approach that involves a geographical and economic prospective to understand the dynamics of urban growth in central metropolitan areas which are undergoing a technocreative process of regeneration $[3,8-10]$. In particular, the geographic analysis is supported by the theory of spatial regulation, which leads us to understand the urban system and its economic and territorial innovations based on the post-fordist economy [1].

\section{A Few Methodological Points}

This paper is based on a number of methods, including 13 semistructured interviews, some done on site, others by phone, as well as a detailed analysis of documentary sources on the Montreal and Barcelona cases. As a start, we obtained information from municipal reports, scholarly publications, newspapers articles, and studies undertaken by various institutions. Then, in-depth semi-structured faceto-face interviews were conducted with experts and local authority representatives involved in the governance of both areas.

As for the choice of cities, we need to say that it is justified to compare these two cities and to try to draw lessons from Barcelona, as the two cities have similar sizes, are not the capital city of the country, but both are known as vibrant cities with a distinctive culture.

To complement these elements, we can highlight some similarities between the actors and local contexts in Barcelona and those in Montreal which can support our comparative approach. These similarities between the 22@ and ID districts are as follows.

(i) They are both exindustrial zones converted into technological territories of predominantly small- and medium-size enterprises, which have networking relations in terms of complementarities and competitiveness.

(ii) These territorial contexts (22@ and ID) encompass both public and private higher-education establishments and research/scientific institutions, creating a mutual synergy between the high-technology clusters and the academic fields.

(iii) These "new neighborhoods" represent the link between an innovative local atmosphere and the global city networks.

(iv) Barcelona and Montreal's communities embedded in these quarters have a deep creative and cultural background.

(v) The local actors work closely with private and public institutions.

(vi) The important role at the first phase of public financing processes which follow a top-down strategy of economic regeneration.

(vii) Barcelona and Montreal are the most dynamic and vibrant cities in their respective regions.

(viii) They are transforming their economic life according to the most advanced sectors of the knowledge economy.

(ix) They are recognized as creative and cultural cities both at national and international level.

(x) Creativity and innovation are two key assets of restructuring processes both in Barcelona and Montreal.

While lessons and policies cannot be transferred automatically from one place to another, research has shown that, 
in the field of urban development and policies, it is often a very useful method [11]. We need to add that the distinctive culture (Francophone for Québec versus English Canada, and Catalan versus Spanish for Barcelona) has developed a strong interest for comparative work between the two cities, as actors and institutional agents feel that many political and institutional dimensions can be compared usefully for learning and transfer of experience. Of course, learning and transferring does not mean copying the exact same strategies, but really learning from experience, by comparing in as much detail as possible the experiences in order to gain insight from the other $[6,12]$.

\subsection{Technocreative Clusters and Technologic Districts as a} Model of New Urbanization in Barcelona and Montreal. Cities have become pivotal driving forces of development, locally in terms of regeneration of depressed areas and marginalized sectors and globally for regional competitiveness and transborder cooperation. Cities are technohubs of global flows, and they play the role of centers of innovation, as well as of new production and creativity regulated by relations of competitiveness and cooperation $[2,11,13,14]$. The current development of the knowledge economy, regarding networks and pipelines of material and immaterial flows of production and technocreative innovations, highlights the economic paradigm in which goods and services are not tied up, as before, with the local factors of the Fordist system $[2,15,16]$. Cities play a paramount role in structuring the governance of economic spaces through a range of multidimensional processes which involve different socioeconomic actors [1, 17-19]. Local stakeholders polarize resources in terms of knowledge, skills and capital in specific regional hubs for implementing socioterritorial innovations and fostering creative networks of production $[6,11]$. Cities become regional poles of development supported by clustered local economies and technometropolitan sectors of growth. They play an important role in the growth of local economies supported by the dynamics of concentration, flexibility, and clustering specialization of economic activities $[16,20,21]$. Camagni and Maillat [10] suggest that the citynetwork can be read along different urban dimensions, considering temporal and spatial vectors, as well as inner and outer spaces of multiple territorial organizations. Some other scholars suggest that the hierarchy of ranks among urban functions has been transformed into a hierarchy of networks, which leads to reposition cities in terms of their global organizational clustering systems (see $[15,17,18,20]$ ).

We could also refer to the works of Richard Florida and the creative class thesis. Florida's three major books $[22-24]$ as well as Landry $[15,25]$ and Glaeser's [26] work have promoted the ideas of creative sectors having an effect on urban development While there has been criticism of some elements of Florida's work, from the point of view of inclusion and social cohesion in particular [27], these authors have all had an impact on the field of urban economics, especially in regard to the creative city thesis, but also on the field of urban policies and urban development $[28,29]$.
Another element which is important in our theoretical framework is the issue of proximity. In the field of industrial cluster studies and explanation of innovative developments [30], researchers' interest has progressively shifted from physical or geographical proximity to relational proximity in order to explain success in terms of innovation or creativity. Indeed, while both physical and relational proximity can be intertwined, and possibly more so in the service and creative sectors, there is more and more agreement on the fact that physical proximity is insufficient to foster innovation and development. It does not appear to automatically have an influence on a sector or a firm's capacity to be creative or innovative. On the contrary, the relational dimension of proximity, that is, access to information networks and personal interactions in a given context, is key factors when a firm or an individual decides to create or innovate $[31,32]$. In other words, although the fact of physically cohabiting with other firms is apparently of less importance than what was originally thought, it can have an influence on a firm's capacity to create or innovate if it also translates into relational proximity. This relational proximity dimension brings us to consider cluster theories, as these are based on strong interactions between actors.

Indeed, the high-tech districts, as well as techno-creative clusters, have emerged as new models of regional development based on the relation between territory and socioeconomic innovations $[6,8,33,34]$. At this point, if we take into consideration a large number of cities and regions around the world, including Barcelona and Montreal, we could argue that local interactions play a key role in supporting the development of innovative sectors of production. In particular, proximity is a key factor of clustering development because it encourages interconnections, linkages, and knowledge exchanges because of its physical, relational, and organizational dimensions $[1,12,16]$. Recent studies have analyzed how the geographical factors of proximity support the economic dynamics in terms of techno-creative clusters and technological districts which transform the regional assets of growth [2,21,35-37]. The urban scientific parks represent this model of urban change both as economic poles and as territorial districts of creativity and innovation. In this way, the 22@ in Barcelona represents a kind of organization of socio-economic revitalization that could be interesting for the future scientific park of Montreal (ID). Although the increased flexibility in production processes and economic services has favored the vertical disintegration of spatial relationships, we observe that a new dimension of industry localization has been highlighted recently on the basis of a close spatial proximity and mutual synergies. In the last twenty years, economic theories have focused on these new phenomena of polarization and territorial innovation, seeking to analyze the regional development processes by functional, systemic, and relational perspectives [7].

The milieux innovateurs [8] and the technopoles [3] approaches can be considered interesting as they represent two theories aimed at clarifying the local dynamics of development and, in particular, the relation between territory and innovation. While the technopole theory is more limited, as mentioned above, the milieux innovateurs theory focuses 
on the socio-economic factors which produce innovation and development in a specific territory. In this case, the territory is very important because with its local and environmental elements, it can create and support the innovation process as an endogenous factor of development. Relational proximity is also important as the local actors and the nature of the territory are the main assets of socioterritorial innovations and the interaction process between varieties of players represents a crucial role in the innovation dynamics. Therefore, this approach appears useful for our study on the urban scientific parks of 22@ and ID. In fact, it takes into consideration as a focal issue the closing synergies and interactions between local actors and the specific features which foster the economic development in terms of territorial innovation and creativity. The territory is considered the core and the active pivot of innovation both concerning its socio-economic structures, and considering its relational and organizational networks $[8,14,33,38]$. The territory is considered as a specific platform of multiple actors which must achieve common targets of sustainable development and shared governance. In this case, innovation is a factor of development which constitutes the nature of a particular territory as well as a strategic asset of growth generated by local resources.

Following this approach, the mutual synergy and the cooperation between different actors are the crucial elements for supporting the territorial innovation and the cultural creativity process. However, the theory of the technopole does present some interesting elements, as a complementary framework. Technopoles can be interpreted as local productive systems that permit the implementation of a new economic organization of regional growth based on the high-technology industry. They form a new economic framework of local system as well as territorial expressions of an international network of technological production. Therefore, the technopoles are a focal point of new interactions between local and regional economies [3]. They are technological centers of innovation and creativity, as well as they represent new urban centralities of social and territorial regeneration. They symbolize a key role in the economic revitalization based on the high-technology activities and social innovations of a specific zone (like the central dismissed industrial areas of 22@ in Poblenou and ID in Bonaventure Area). Usually, they are supported and financed by local governments which are connected with universities and R\&D centers. This is motivated by a will to increase the growth of high-technology industry and scientific production, as well as by the creation, attraction, and promotion of new firms and innovative sectors. They foster the territorial and economic regeneration supporting the synergy and the knowledge exchange between different players which share trajectories of development and goals. Indeed, we can consider the technopoles as specific poles of economic attraction in which different players boost the high-technology industry and scientific productions. Some scholars have analyzed these dynamics of agglomeration according to technological development and concentration of creative firms into a specific area like ID and 22@, which have been already defined "milieux technopolitains" $[1,3,8]$.
These relations and linkages form a kind of atmosphere of intensive exchange of knowledge and creativity in the territory which supports and provides socioterritorial innovations in the area $[6,39,40]$. The socioterritorial innovations are the fundamental factors which sustain the local development process in the ID as well as they encourage the building of strategic partnerships between scientific/research environments and firms. The techno-urban parks as the Innovation District are territorial and economic microsystems of innovation based on high-technological firms and supported by institutional, private, and scientific networks with intensive and structured relations.

On the basis of these approaches, we can consider these two districts as "open technopoles of new generation and innovative scientific urban parks" which are generating "hybrid" technological districts. We can argue that this emerging territorial organization as new urban technoscientific park contains the main characteristics of the functional technolpoles, but, at the same time, it goes beyond this by the establishment of a more relational dimension. Indeed, within these clustering dynamics, the mutual interactions and multilayered relations between different public and private players are modeling the spatial, social, and economic strategy. In this case, we can observe how the relationalbased approach plays an important role in the restructuring and regeneration of the 22@ and the Innovation District. We observe that in both neighborhoods the relational approach in terms of new clustering process tends to be complementary to the more traditional technopolitan development strategy. However, we can observe in the 22@ and in the ID different levels of integration between the two approaches. The first seems to be more linked to a functional dimension, even if it provides important lessons to Montreal in terms of new experimentation of urban strategies of development and new forms of governance. The second case is in the initial phase of development and can therefore take advantage of Barcelona's experience in terms of urban policies and clustering organization and, as well, upgrading and implementing the social and relational features in the urban regeneration process (which have been insufficiently considered in the 22@strategy).

Definitely, we observe that Poblenou and the emerging Quartier de l'Innovation are based on a high level of territorial innovation as well as a demarcated spatial concentration of new economic activities. On the one hand, the clustered territorial system in the both quarters fosters local economies with reference to local assets and indigenous skills [41, 42]. On the other hand, it activates a series of dynamics which generate development at both regional and national levels in order to lead the economic changes from local to global systems [10, 43-45]. 22@ and ID represent these dynamics of local/global interaction where urban scientific areas tend to connect and improve local assets and endogenous innovations in order to upgrade their local systems in the global competitive networks.

It is important to clarify how lessons and institutions generated in Barcelona can be transferred to Montreal and what kind of adaptation could be done in Montreal. As a first step, in our study, we hypothesize that public intervention 
(top-down policy) in 22@ has generated the cluster formation, because it has been developed following a top-down strategy of governance. In the ID case, we hypothesize that a variety of multiple players/actors will form a hybrid and horizontal platform of governance. Consequently, a network of actors in the ID is building a significant platform of players formed by institutions, enterprises, research centers, and universities. In this case, the model of regional development based on the interfacing synergies of local stakeholders is crucial to understand how clustered technological districts can transform their functional organization and play a role in changing the economic assets of the postmodern metropolis [46]. We can argue that it is very important to observe the Barcelona's lessons in terms of polarization of economic and creative actors in a particular territory which has been transformed in its strategic assets. As well, we know how it is important to observe the main instruments and policies of regeneration that are playing in the case of 22@ an important role of reconversion and radical change. However, although we consider Barcelona's renewal process as the main framework of reference for the ID in Montreal, we can consider that the Catalan case represents more an urban experience in terms of governance and territorial change than an "urban pattern" which can be adapted or transferred directly in the Montreal context. Of course, we can take advantages of some important elements which play a key role in Barcelona, but we are convinced that, during this emerging phase in the Innovation District (10 years after 22@), it will be more interesting to evaluate the innovative features of 22@ that could be useful to generate and implement a new creative Montreal strategy.

\subsection{A First Approach between 22@ and the Innovation District.} The first part of this study examines the transformation of Poblenou into the techno-creative district of 22@. We initially highlight the factors contributing to the socioeconomic transformation of this area and their effects on the neighbourhood. Consequently, the second part investigates a specific area embedded in the southwest portion of Montreal, which could take advantage of the 22@'s experience to establish guidelines to be used to design its own development plan. Indeed, this particular quarter denominated Bonaventure Area is going through a period of major changes. It seeks to reposition itself as the "Nouveau Quartier Innovant" (QI) of Montreal [47]. This exindustrial neighbourhood, located between the Old Port and the Lachine Canal, bordering Griffintown and embedding the Multimedia City and the City of Electronic Commerce, represents a specific urban district with high-technological vocation $[6,48,49]$. Why have we chosen to study the territory of Poblenou in Barcelona and carry out a comparative study with the Montreal metropolitan area of ID? Not only could we easily observe some similarities in the geographic, political, and socioeconomic profiles of both urban regions but also there are two main reasons for carrying out this comparative study.

First, both Barcelona and Montreal represent metropolitan spaces of intensive technological growth polarized around external periurban corridors as well as concentrated in central neighbourhoods like Poblenou-22@, Griffintown, Bonaventure Quarter, and the Old Port. It is interesting to assess how 22@ can serve as both a development model for Montreal and an international reference point for a better governance of future urban policy. Second, the urban strategies elaborated by the Provincial Institutions of Quebec and the City of Montreal have shown interest in the 22@ regeneration project as well as a model of governance. Creativity and innovation are two key factors of development for both cities, sustaining the repositioning of their strategic neighborhoods (22@, Lobregat, El Besos, El Prat, Cité du Multimedia, Cité du Quartier Bonaventure, and Commerce Électronique). These zones are strategic areas which represent two dynamics of urban renewal. (a) The restructuring of central neighbourhoods according to a multifunctional and multilayer perspective of uses. (b) The development of local economies founded on the synergy and complementarities between knowledge-creative clusters. These clusters are formed by private and public firms, local communities, associations, and authorities as well as universities and R\&D institutions. They are supported by local resources and an endogenous atmosphere which characterizes the creative ID@ city. These techno-creative districts are defined by their features of flexibility, multidimensionality and multilayered processes of economic production [50-52]. According to Van den Berg's model of urban cycle life [53], we could describe this urban restructuring as the final phase of a long process of urbanization which identifies the last regeneration in terms of innovation and creativity. These "innovative innercities", identified with the techno-creative clusters represent the new urban centralities embedded into urban scientific parks. This issue is evident in the maintenance and restoration of historical and industrial sites (e.g., Poblenou area and Canal Lachine Park). It shapes the identity of former economic sites as well as part of the texture fabric of the postmodern city. There is currently in Montreal an emergence of new technocreative areas defined by local actors, not yet institutionalized by local governments but coordinated by the scientific institutions, which collectively seek to play a networking role in establishing a new platform of governance. These hybrid spaces of renovation are concentrated in the Old Port and the waterfront area (Vieux Port, Faubourg des Récollets, Lachine Canal, Griffintown, Quartier Bonaventure, and the sector Sud-Ouest) with the objective to generate new creative clusters of innovation and scientific research as well as to develop mixed commercial and residential buildings. To conclude, we believe that the Barcelona model in terms of urban policy and economic strategy could provide important lessons to Montreal governance in order to highlight key elements of reflection, experimentation and planning which are useful to local stakeholders. The local actors in Montreal, mostly the institutions and the city's government could take advantage of 22@'s experience as it represents a topdown policy which has invested and financed the clustering territorial process of regeneration. We will highlight some key elements in terms of structures, infrastructures, and social organizations which have been established in the 22@ with the aim to support and implement the renewal, in order to provide to Montreal's (and eventually other cities') actors 
several guidelines and evaluate the future impacts in the governance process.

\subsection{Hyper-Barcelona: 22@ as a Creative District of Innovation.} The 22@ district of innovation encompasses the former industrial neighbourhood of Poblenou, which was once a concentration of factories and industrial sites that served the entire region of Catalonia. It has gone through a very difficult period of socio-economic depression and marginalization, as well as territorial fragmentation before being revitalized into an innovative multiclustered district. It used to be considered a concentration of brownfield sites and degraded areas, cut off from the rest of the city and not integrated into the metropolitan fabric. An important factor of transformation has been the 1992 Summer Olympic Games, which resulted in renovation initiatives all over Barcelona. This manufacturing district used to be a vast degraded and fragmented space. Due to its functional characteristics and its centrality, Poblenou later became attractive in terms of clustering of innovative economies [54]. The first modern industries of Barcelona were established in this district from 1850 onwards, taking advantage of the abundant underground water sources, free and open spaces, and the ease of access to the port, which acted as a gateway for incoming raw materials and coal, as well as manufactured goods-mostly textile production-exported to foreign markets. Later on, the food industry and agricultural market developed alongside the textile sector and the metal industry, the last of which became the dominant sector in the area. Recently, at the end of the 1960s, with the relocation and dismantling of many such industrial sectors and areas, logistics and transport became the main sources of economic development (see [54-56]). Up to here, a long process of urban decline affected the district which could not restore its identity, but only emphasized the discontinuities between the area of Poblenou and Barcelona caused by the railway lines and the different city plans (Cerdà grid 1859-1953; Country Plan 1976; General Metropolitan Plan 1980).

Today, the transformation of the industrial area of Poblenou is part of a larger strategic plan developed for the eastern side of Barcelona (La Sagrera, Rambla PRIM, Diagonal, Besos). This plan includes

(i) a new high-speed intermodal railway station (La Sagrera);

(ii) a new regional/international hub (Plaza de las Glories);

(iii) new urban multifunctional spaces (e.g., Media-Tic building and Torre Agbar).

The reforming process of the area began in 2000 with the elaboration of a strategic plan to achieve a radical transformation of the Eastern part of Barcelona and to establish a new socio-economic identity [57]. The urban policy aims at creating in the next ten years (2020) a great technological neighbourhood based on the innovative sectors (NTIC, Multimedia, Energy, Biotechnology, and Design). The denomination of 22@ was established considering the criteria for the transformation of the land previously classified as industrial land by the PGM (22a classification). The 22@Plan establishes the criteria for the conversion of the obsolete industrial areas into a sector suited to new forms of production based on the information and knowledge economy. It is a district of "excellence" and creativity: an attractive zone of innovation and technology based on the multiclustered sectors.

It aims at increasing local assets of growth to foster global networking skills through international partnerships [58, 59]. The 22@ district represents the combination of its local dimension - as a set of territorial and economic characteristics, such as social and territorial identity and social and cultural fabric of the territory-and a global economic dimension. The director of the Urban Planning Office of Barcelona affirms [56]: "22@ represents the new key of urban planning which the Barcelona Government wants to foster in order to change the territorial uses and the economic features and transform Poblenou into a technological district." We can affirm that 22@ is a challenge for both Barcelona and the overall Mediterranean regional system because it represents the chance of repositioning and restructuring the European outline which is too oriented towards Central Europe [60].

\subsection{The Industrial Area of 22@ between Urban Regeneration} and Knowledge Economy: The New Urban Technoscientific Park in Barcelona. The 22@ project embodies an urban and socio-economic change, moving from a former textile and logistic industrial area to an innovative neighbourhood in order to implement the process of urban planning and to revitalize the local economic system. This twofold strategy has been formulated to attract innovative firms belonging to five clusters (New Information Technology and Communication (NTIC), Multimedia, Medical Technology and Biotechnology, Design, and Energy). It is important to note that a focal role in boosting a clustering concentration has been played by research centers (R\&D) and specialized university departments which have supported the agglomeration process and the attractiveness of high-tech firms. But some experts affirm that this strategy has been too fragmented and oriented towards an economic revitalization, without considering socio-cultural parameters. This is a critical point that could be useful to better address the ID local policies in Montreal. At last, the final target has been to develop the territory of Poblenou with the objective of building and raising a multi-clustered technologic district of knowledge economy. Project 22@ was planned following two main strategies:

(i) developing a master plan in order to build a new creative neighbourhood;

(ii) achieving the reconversion of economic activities for the attraction and promotion of local and international firms in Poblenou.

Until now, the local actors (public and private) have established new and flexible criteria of governance to transform the neighbourhood into a creative advanced district as well as to define a range of significant targets which must 
develop a multimodal platform of production, innovation, and creativity.

22@ embeds this territorial platform: it represents a hub of networking players and interfacing areas based on the multiscalar and transversal relations. The synergy between institutions, business communities, universities, and research centers should be the main factor of strategic governance (e.g., the Network of Science and the Technology Parks of Catalonia in 22@-XPCAT). Since its foundation in 2000, the innovation district has managed to attract more than 1,400 firms in the fields of NTIC, biotechnology, multimedia and energy, thus also attracting national skills and talents to activate a process of revitalization aimed to transform Barcelona into the digital city of Europe. Nonetheless, some prestigious universities (IESE, ESADE, EADA, UB, UAB, UPC, UPF, URL, UIC, UOC, and IAAC), R\&D/R\&I centers, and digital services like “infrastructures 7@” have created a successful platform of synergies, exchange, and interconnections in Catalonia. Thus, the urban reform of the metropolitan plan of Poblenou (PERI) is founded on the new economic activity 22@ and technological services with the aim to change the local assets and the economic organization. We observe that more than half of the companies installed in the 22@, 53 out of 100 exactly, operating in either of the four areas of excellence- that are ICT, Multimedia, Biotechnology, and Energy, have intensive relations with the research centers and universities.22@BarcelonActiva, the local development agency, plays a strategic role in supporting and attracting local and foreign companies. Poblenou went from being considered a depressed and fragmented area, with only about $2 \%$ of Barcelona's economic activity in the industrial area and $4 \%$ in the urban area, to a new economic centre. Today, $70 \%$ of the new firms operating within22@ are considered strategic clusters (the 4 areas of excellence mentioned above plus the addition in September 2009 of a fifth clusters, Design) and are located in this neighbourhood. $45 \%$ of these new firms are a "new creation" with 42,000 new jobs (the future perspective is 150,000).

Poblenou was an intensive zone of industrialization and production called "the Catalan Manchester" because it represented a huge vertical agglomeration of heavy industrial firms. Many years later, the economic crisis has made this port area collapse. It has also created a deep degeneration process of territorial fragmentation and economic marginalization. Nowadays, the global context is changing and a real strategy of regeneration has been approved with a special plan of reforms (2000). The area is growing fast, with a perspective of development relaunching a new economic model based on the hightechnologies. There are five clusters of development transforming the industrial area into an integrated innovation district. These clusters represent the new hybrid model of urban governance between the technopole approach and relational and open clustering framework. Poblenou reflects this experimentation by which the functional and scientific strategy tends to be complemented by a relational-based model of development. According to this perspective, the five clusters are classified in terms of territorial localization, typology and accessibility, and spatial planning. These clusters include, MEDIA (Multimedia), NTIC, Biotechnology, Energy, and Design (Table 1).

The first four clusters are located in specific zones, but the last one is spread over the territory without a special perimeter. We believe that this territorial organization in four main hubs gives the clustered process a better integration. Storper and Scott [19] suggest that this synergy among clusters stimulates and increases the competitiveness and the complementarities in order to boost and upgrade the local economy. An important role is assumed by universities (10 national and international academic institutions with 25.000 students) which are planning establishments in the district with many departments and research centers which are connected with the business sectors.

The main actors playing a role of supporting and developing this process are the following.

(i) Strategic firms embedded and clustered in the area with specialized knowledge and expertise.

(ii) Local and national Institutions (e.g., BarcelonActiva, Puerta 22).

(iii) Universities and R\&D.

(iv) Specific incubators and multi-functional services managed by local associations.

(v) Strategic networking platforms of different stakeholders which can exchange information, innovation and knowledge.

Thus, the informational city_the @city seems to build a new morphology of urban space which provides Barcelona with a new dimension of urbanization. To conclude, 22@ represents a special place where technologic and social processes of territorial organization are building a renovated neighbourhood which is formed by an interconnection of "xarxas" (networks) based on creativity and innovation. 22@ represents the edge-city, the informational city, the heteropolis or the hub city which has lost the traditional and linear relation between the center and its suburbs in favour of multiple centralities [61-64]. During an interview, the second chiefarchitect of 22@ says: "I believe that urban planning strategy should develop and take into account some focal points like rethinking to a social and an economic development process in order to increase the level of attractiveness and competitiveness in terms of infrastructure, accessibility and quality of life...we cannot plan a space without considering social, creative and cultural elements...22@-district of Poblenou is a product of these changes which are modeling the morphology and the nature of the territory, not only in its physical dimension but mostly in its digital and virtual features, extending and transforming the real city into the digital metropolis".

Considering the 22@ project, we highlight some important issues related to policies and strategies.

(i) 22@ is a formula of mixed urban residential, entrepreneurial, academic and training, collective, public and private, commercial, office parks planned by the City Council of Barcelona and approved in 2001. 
TABle 1: Clusters and main economic stakeholders of 22@ District.

\begin{tabular}{|c|c|}
\hline \multicolumn{2}{|l|}{ MEDIA } \\
\hline Firms & MediaPro (Imagina), AND, Lavinia, Cromosoma, Yahoo I+D, Editorial Group RBA, Vistaprint \\
\hline Institutions & $\begin{array}{l}\text { Radio Nacional de España, Consell de l'Audiovisual de Catalunya (CAC), Barcelona Televisioò, Audiovisual } \\
\text { Production Center (PMB) }\end{array}$ \\
\hline University & Pompeu Fabra University (UPF), University of Barcelona (UB), Open University of Catalunya (UOC) \\
\hline Technological Centres & Barcelona Multi-Media Centre of Innovation (CIBM) \\
\hline Incubator & MEDIA-TIC Building (Consortium Zona Franca+22@)_Imagina Building 12.000 msq (22@+MEDIAPRO). \\
\hline Residence area & Melon District and Ciutadella \\
\hline Synthesis & $\begin{array}{l}\text { The role of actors is based on a deeply connection and convergence among several public and private } \\
\text { institutions. It is the stronger cluster in 22@ }\end{array}$ \\
\hline \multicolumn{2}{|r|}{ C } \\
\hline Firms & T-Systems, Indra, Telefonica I+D, Yahoo Europe, Casio, Orange, ONO \\
\hline Institutions & (CMT) Market and Communication Commission, (FBD) Fundació Barcelona Digital, Localret \\
\hline University & UB, UPC, La Salle \\
\hline Technological centres & $\begin{array}{l}\text { Techno-Center TIC Barcelona Digital, TIC House (Council of Barcelona+Fundaciò Barcelona } \\
\text { Digital+Generalitat of Catalunya) }\end{array}$ \\
\hline Incubator & $\begin{array}{l}\text { Edificio Media-TIC Barcelona Digital (ACC1Ò) strategic point of Catalunya technological network, } \\
\text { 22@Interface Building }\end{array}$ \\
\hline Residence area & Melon District \\
\hline Synthesis & $\begin{array}{l}\text { NTIC is a key asset of cluster development and point of reference for European networks. Two examples of this } \\
\text { progressive growth and interconnection are 22@Living and Lab (22@Barcelona+Fundacio Barcelona Digital). } \\
\text { They represent a kind of urban laboratoryspace connected with other urban laboratories, supported by public } \\
\text { and private firms and associations. The other project is denominated "ICING" (Innovate Cities for Next } \\
\text { Generation), that is, an European program for enhancing and promoting research and development activities } \\
\text { in urban areas. }\end{array}$ \\
\hline \multicolumn{2}{|c|}{ TecMed-Biotechnology and Medical Engineering } \\
\hline Firms & Matachana, Gaes, Sanofi Aventis, Isdin, Telemedicine, Camp I Jové \\
\hline Institutions & Banco de Sangre and Tejidos, CatSlut, CIDEM, BioRegion of Catalonia (Blocat) \\
\hline University & UB, UPC, UOI \\
\hline Technological centres & Building Health, Business Park BIO Barcelona (PCB-UB), Research Bio-Medical Park of Barcelona \\
\hline Incubator & TecMed 22@LAB \\
\hline Residence area & Nido \\
\hline Synthesis & R\&D and R\&I centers are the main actors of development \\
\hline \multicolumn{2}{|l|}{ Energia (ITER) } \\
\hline Firms & Endesa, Ecotécnia, Agbar \\
\hline Institutions & ITER, IC3, CETAQUA, European Agency of Fusion \\
\hline University & $\begin{array}{l}\text { UB, UPC, Escola d'Enginyeria Industrial de Barcelona, IREC (Instituto de Investigacion en Energia de } \\
\text { Catalunya) }\end{array}$ \\
\hline Technological centres & No \\
\hline Incubator & Besos Interuniversity Campus, Business and Technologic Campus de Barcelona (b_TEC)—148.266 mqs \\
\hline Residence area & b_TEC \\
\hline Synthesis & $\begin{array}{l}\text { The ITER is a research and development project experimented to produce electrical energy through fusion at } \\
\text { world scale. The ITER's headquarter is based in France (Cadarache), but 22@ hosts the European Fusion } \\
\text { Agency which coordinates ITER. }\end{array}$ \\
\hline \multicolumn{2}{|c|}{ Design and Architecture } \\
\hline Firms & G-STAR Raw, ADD, Node, Morera Design, Ruis+company, Estudi Arola \\
\hline Institutions & $\mathrm{BCD}$ \\
\hline University & Palo Alto, PBM, Hub Design, University of Vic, UPC, IAAC \\
\hline Technological centres & Barcelona Media Center of Innovation \\
\hline Incubator & Media-TIC, Project Bressol Moda \\
\hline Residence area & Melon District/Ciutadella \\
\hline Synthesis & It represents the emerging cluster borne in September 2009 \\
\hline
\end{tabular}


(ii) The new approach of development classifies the territory not only as an industrial space but also as a residential and economic area (the new urbanism of 22@ policy has modified the Master Regional Plan formulated in 1976).

(iii) 22@ takes the traditional economic system and restores it towards an innovative urban, architectural and environmental identity, and therefore transforms the industrial areas into a new model of compact and rational city [65].

(iv) 22@ will be reformed by a special Master Plan which provides a complete high-quality urban environment change in order to reduce the environmental impact of infrastructures and mobility (Diagonal Street, Glories square and Sagrera Station; Bixi System).

(v)22@ represents the new centrality of Barcelona; it is accessible through three main doors rich in territorial and cultural identity: the Agbar Tower built by Jean Nouvel, the Forum of Culture built in 2004, and the future station of the AVE Sagrera $[56,66]$.

Borja [64, page 163] suggests "The limitations of Barcelona's model appeared after twenty years of consensus and positive factors that have had a lifetime of logical and functional dimension but are now gone... generating perverse effects of urbanization... Then we need to innovate in the urban policy and the urban culture in order not to re-create a social segregation model, pursuing the multifunctional and multidimensional development model."

The movement of opposition to the project 22@ currently relies on a series of movements of neighbourhood committees and associations, as exindustrial and worker area associations, having a strong tradition of social activism. There are four associations that try to claim the rights and the will of the citizens and inhabitants of Poblenou, in order to influence the public debate on management decisions and plans. Three issues are discussed: (i) the criticism of the process and management decisions and strategies; (ii) the criticism of the type of urban projects formulated by decision makers; (iii) the criticism related to social costs arising from the implementation of projects that lead to various adverse effects, including the process of gentrification.

The associations mostly denounced the lack of public participation in drawing up the plan of urban district (PERI) and the pressure from real estate interests. Moreover, a strong point of contention is the urban planning in terms of height of buildings and building landscape. The theme of the debate has shifted from a discussion about the reconversion of buildings and activities to a deeper intellectual discussion concerning the landscape and industrial heritage that should be protected and preserved as a historical memory. Ultimately, it is opposed to an architectural model that is alien compared to the existing urban fabric and compared to the social reality of the neighbourhood. Therefore, it is important to note how fundamental it is to maintain and support the archetypal Barcelona's model that was the key factor of good practices. To summarize, despite the fact that the 22@ model is able to provide to ID in Montreal some important elements of development, we can highlight three points which have limited the process of regeneration in the Catalan district.

(i) A distance between the real estate interests and the social components of the neighbourhood.

(ii) The limited participation of local community and social groups in terms of planning and governance.

(iii) The process of regeneration has been more focused on the relations between private promoters and local institutions than on the synergy with scientific and research institutions.

2.5. The Innovation District in Montreal: A Comparative Analysis of an Emerging District in terms of Potential Integration and Future Governance. The Innovation District represents a potential area of development in Montreal. It is located between two different arrondissements (Ville-Marie and Le Sud-Ouest), and it embeds a strategic zone of economic revitalization. The territorial framework is very interesting because it is expected to be the first scientific urban park located in Montreal's core. The local policy formulated for the Innovation District (ID) has considered as a fundamental axis of regeneration the urban strategy "Montreal 2025Montreal Technopole" which plans to transform Montreal into an international creative city $[36,40,67]$. Montreal will represent the new metropolis which will be characterized by a high level of innovation and creativity [68]. In the area of Southwest where the ID is living its first process of territorial organization and planning, we can highlight four main strategies of development focusing on the following.

(i) Attracting and establishing emerging new firms and innovative economic sectors (NTIC, Multimedia, Biotechnology and Engineering and Electronic clusters).

(ii) Fostering and boosting partnerships and connections between scientific community and business environment in order to develop a mutual synergy.

(iii) Developing an urban and multifunctional scientific park which reproduces a real living neighborhood.

(iv) Creating an incubator pole for scientific production and research activities.

The main stakeholder and promoter of the ID is the ETS (École de technologie supérieure), a university which aims to develop and to encourage future partnerships among different institutional and academic players. The main targets elaborated in order to boost and plan the Innovation District are the following.

(a) Building a new urban centrality denominated by an ecosystem of innovation where the ETS will be the center of the urban scientific park.

(b) Encouraging the process of clustering innovation and promoting "incubators as cells of open innovation" like the new project INGO (Carrefour d'Innovation) which embeds the quadrilateral area of the Brasserie Dow. 


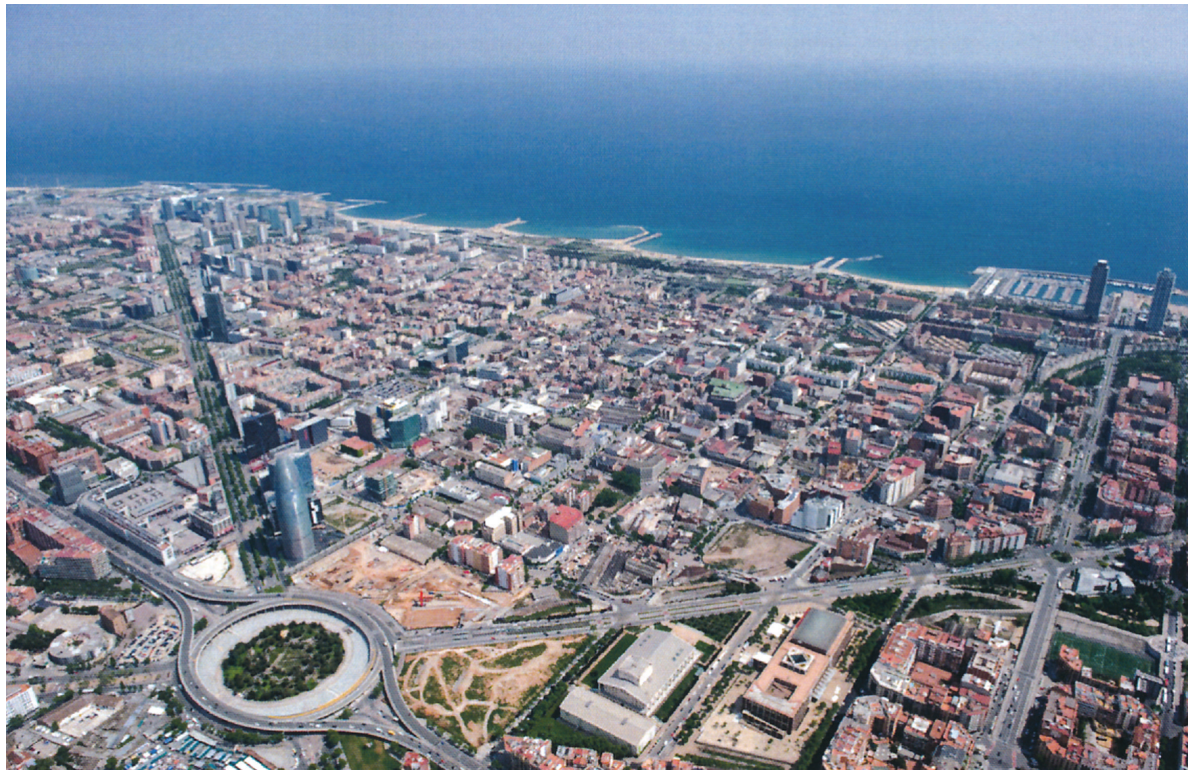

Figure 1: 22@.

(c) Integrating the techno-creative quarter with the cultural corridor of the Ottawa street and Griffintown area, in order to promote a multidimensional area and multi-functional pole based on art and creativity.

(d) Developing an urban regeneration strategy for implementing the quality of life and a sociocultural perspective in the area.

Thus, the ID@_ecosystem of innovation-could represent the new regenerated neighborhood in Montreal as is the case for the district 22@ in Barcelona. The following table compares the two districts, and it seeks to highlight their differences (Table 2), while Figures 1 and 2 show the actual locations in Barcelona and Montreal.

Definitely, the ID@ represents the biggest regeneration project in Montreal which seeks to plan and to reform the industrial area of Canal Lachine. We can observe different actors which play a key role in the different zones and functions. The main local players and the central areas of urban change are

(i) ETS and its buildings and surfaces (Coordinator hub),

(ii) Bassin du Nouveau Havre,

(iii) Griffintown as main creative and cultural area,

(iv) Nordelec as main incubator actor of innovative and creative firms,

(v) Cité du Multimédia (techno-cluster),

(vi) Planetarium (New space for R\&I),

(vii) Cité du Commerce électronique,

(viii) Residential area of Jardin Windsor,

(ix) Quartier Bonaventure.
The potential framework of territorial regeneration defines different multiuse areas which are embedded in the Innovation District (ID). The ID must build an integrated system of governance elaborated by local actors in order to exchange knowledge, savoir-faire, innovation, and talents and to make a new space of regulation for this territory [69].

During an interview, the director of ETS says "It is necessary to implement and foster the process of regeneration through multiple criteria of innovation. The innovation must be an open and hybrid innovation as well as rich in technology and social features. We must produce socio-territorial innovations and create an urban park where the research and training activities as well as the scientific and industrial productions are interconnected with the dynamics of the neighborhood. . An important example is the project INGO which aims at creating new cells of innovation based on this incubator-space in order to attract activities and firms related to the scientific sector of ETS...It will be essential to increase the integration process in all its different dimensions (spatial, territorial, economic, creative, organizational, relational and institutional), and the ETS plays a key role to establish a strategic partnership...The innovation District (ID) will also see a growing number of talents and researches. Today 20.000 workers work in the knowledge economy sectors and they live in the neighborhood". We must create a kind of agglomeration and concentration of different actors if we want to attract the innovation and the creativity in the neighborhood. We must create a kind of open ecosystem of innovation and increase the interconnections at all levels in order to sustain an open innovation in the territory and develop a real living neighborhood." The open innovation involves a new approach which transforms the innovation management system within large- and mediumsize enterprises. Rather than limiting themselves to their R\&D in order to develop new products or new services, more and more firms prefer to establish strategic alliances with 
TABLE 2: 22@ and ID: differences.

\begin{tabular}{|c|c|}
\hline 22@ & Montreal's Innovation District \\
\hline Platform of innovation & Ecosystem of innovation \\
\hline $\begin{array}{l}\text { Consolidated multi-clustered district ( } 4 \text { consolidated clusters } \\
\text { and } 1 \text { emerging) }\end{array}$ & $\begin{array}{l}\text { Emerging clusters of innovation (2 consolidated clusters (Cité } \\
\text { du Multimédia and Cité du Commerce Électronique)) }\end{array}$ \\
\hline $\begin{array}{l}\text { Economic and territorial regeneration fostered by } \\
\text { institutionalized top-down strategies }\end{array}$ & $\begin{array}{l}\text { Socioeconomic regeneration based on scientific and strategic } \\
\text { partnerships boosted by multiple actors (réseau ouvert des } \\
\text { acteurs) }\end{array}$ \\
\hline $\begin{array}{l}\text { Real estate interests and innovation in terms of attractiveness } \\
\text { of firms and institutions (strategic platform of governance } \\
\text { among major actors) }\end{array}$ & $\begin{array}{l}\text { Research activities and innovation in terms of academic and } \\
\text { scientific pole and strategic partnerships (strategic ecosystem } \\
\text { of innovation) }\end{array}$ \\
\hline Local/regional/international level of development & Local/provincial/national level of development \\
\hline $\begin{array}{l}\text { Strong level of integration between local institutions but low } \\
\text { synergy with scientific and academic players (top-down) }\end{array}$ & $\begin{array}{l}\text { Emerging networking and connection among local } \\
\text { stakeholders in order to increase integration and synergy } \\
\text { (top-down and bottom-up) }\end{array}$ \\
\hline Key role of local and national governments & Key role of ETS and McGill in the first phase of planning \\
\hline Lack of social life and living neighborhood & $\begin{array}{l}\text { Attention to quality of life and mixture/attraction of } \\
\text { socioeconomic groups }\end{array}$ \\
\hline $\begin{array}{l}\text { European centre of techno-creative networks based on central } \\
\text { metropolitan area }\end{array}$ & $\begin{array}{l}\text { New regional and metropolitan centre of innovation based on } \\
\text { Montreal's New Technopole }\end{array}$ \\
\hline Strong city branding of 22@ since 2000 & Emerging process of identification in $2009-2010$ \\
\hline Surface of project: 200 hectares & Surface of project: not yet defined \\
\hline
\end{tabular}

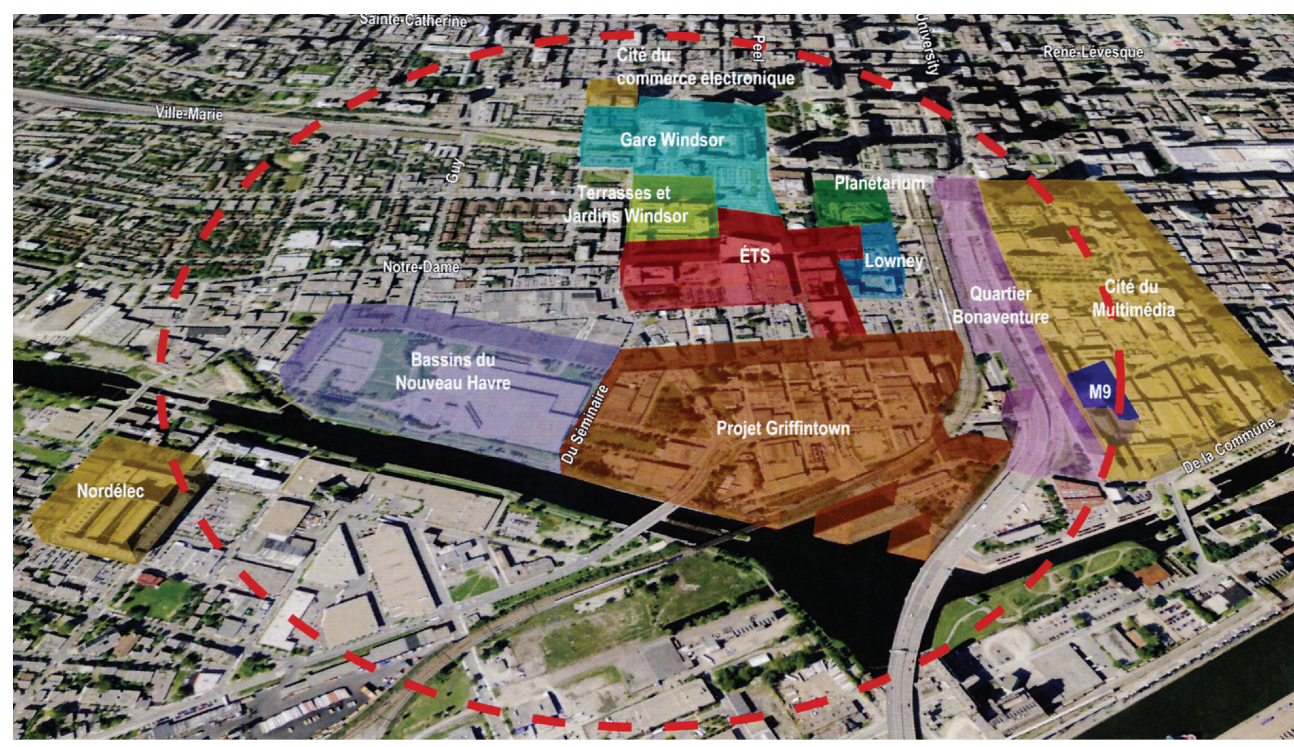

FIgure 2: Montreal's Innovation District.

“external partners" such as universities (McGill and ETS) and research centers.

Therefore, the universities act as pivots of improvement and advanced centers of production. They play a key role in building new relationships with business environments and different socio-economic actors. On one side, they encourage the creativity and the innovation in terms of production and dissemination of knowledge. On the other, they have and form resources in terms of human capital. Thus, the potential asset of development between the Cité $d u$ Multimedia and ETS is very strong since it already represents a significant cluster of media firms concentrated in the area, with almost 6.000 workers. The multimedia cluster operates with many innovative and creative firms, and it has changed the local economy as well as the urban landscape around Canal Lachine. This cluster could be a pivot for development of other sectors, stimulating the emergence of other urban clusters, directly or indirectly, connected with the multimedia industry.

During an interview, the president of a strategic firm which has elaborated the strategic vision of the Innovation District says " The governance of the development process must be able to mobilize the actors in the territory, synchronizing and coordinating different level of synergy in order to achieve 
shared interests. At the beginning, the difficulty is in formulating strong and cohesive strategies of development for each stakeholder...Definitely, our neighborhood must be an open, innovative and living district... must develop a neighborhood life which has been lacking for 22@ in Barcelona...We need to create a true "Living-Lab" based on economic development, socio-scientific innovation and quality of life. In this sense, the ETS has an important role in mobilizing the various actors and increasing the relationships in the territory between universities and business environment. Unlike the Catalan model, we have the chance to create a synergy from the beginning of the process of governance, having the scientific/research infrastructures and a strategic position to build it."

The ETS plays an important role in coordinating the different institutional and private actors in order to develop the Innovative District. To summarize, the main objective is to create an urban technological park and to transform the Southwest neighborhood into a new innovation district $[70,71]$. This special environment enhances the emergence of scientific and business microcosm in terms of bimodular territorial organization which will form an integrated ecosystem of innovation. During an interview, the director of RESO (Economic and Social Coalition of Southwest CDEC) says "The regeneration process is determined by a network of actors from different horizons, which together are forging a strategic synergy to develop this fertile land. The strategic approach in terms of governance must combine technological innovation and social innovation in order to implement a strategy of participation and inclusion of local communities. We must create an open innovation system in the territory rather than a closed innovation system in order to avoid the creation of a technological ghetto. The objective is to develop a hybrid urban park founded upon the scientific research and innovation. . The ETS would catalyze the dynamics of networking as actorpivot of attractiveness and as scientific platform." We must underline that the potential innovation district has already a high concentration of creative industries and innovative firms [47]. This concentration of enterprises is agglomerated into three technopoles.

(i) The Multimedia City (Cité du Multimédia) which includes 70 small and medium innovative firms, specialized in the multimedia and NTIC environments (with 6.000 creative workers) $[4,5,31]$.

(ii) The City of Electronic Commerce (Cité du commerce Électronique) which groups international enterprises like IBM, CGI, CSC and 6.000 workers in the NTIC.

(iii) The Nordelec incubator building with more than 235 firms in the sector of multimedia and NTIC.

The local stakeholders have to valorize the cultural and creative complementarities which are already transforming the territory. The director of the consulting firm "Convercite" affirms "The ETS gave us the objective of elaborating the Master Plan of the Campus and we have made it with a strategic approach in order to plan the territory in two strategic hemispheres like a brain...we develop the left part, dedicated to research and academic performance...the right part will be focused on the creation, production and attractiveness of innovative firms...the strategic goal is to create a kind of technological and creative interconnection and exchange between the research sector (left) and the business sector (right)."

To conclude, the strategic areas like the Bassin de Nouveau Havre, Planetarium, and Quartier Bonaventure represent important spaces of potential regeneration which will strengthen the consolidated hubs (Cité du Multimédia, Cité du Commerce Électronique, ETS, and Nordelec). Therefore, universities and high-technology industry linkages are an essential part of the knowledge transfer for the emerging clusters that rely upon this type of knowledge economy. The large industrial area around the ETS is living a radical change with a population of about 10,000 new residents and $\$ 6$ billion investment envisaged in the long term. In the next ten years, this neighborhood hopes to represent one of the most modern in North America as well as be the symbol of a new identity and brand for Montreal. These areas will embody a new megapole of creative production based on scientific and research institutions (Universities, Departments, and R\&D), innovative clustered firms (Multimedia, Biotechnology, Design, Engineering, and Electronic), and artistic and cultural facilities. The ultimate goal is to create a multifunctional district and to promote a convergence of interests in order to produce a development process based on the integration and mobilization of multiple actors.

To conclude, as shown by the following table, representing some features in terms of urban planning, economic reconversion, and social components, we can transfer some of the most interesting actions and guidelines drawn by 22@ urban strategy (Table 3) to the implementation of the ID emerging district.

\section{Conclusion}

The aim of this comparative study was to analyze the process of strategic regeneration and economic revitalization ongoing in the technological districts and urban scientific parks of 22@ in Barcelona and Innovation@District (ID) in Montreal.22@ and ID are two emblematic cases of central areas which have been revitalized in order to regenerate industrial zones and transform deindustrialized spaces into new centralities of high-tech production and creativity. The first part of this study has analyzed the neighborhood of Poblenou and its multiclustered and creative district of innovation as a model of urban technological park in Europe. The second part has showed the features of the process of governance and development in the emerging ID in Montreal which takes advantage of the best practices of 22@ without reproducing the negative effects in terms of regeneration and planning. On the basis of our analysis, we have analyzed the model of technological parks and districts considering the approaches of milieux technopolitains and technopoles, as the basic socioeconomic structures of these emerging areas. As concerns ID, we have highlighted the role of local stakeholders, such as the scientific and research institutions [47], who play a key role to foster and implement a process of territorial and economic innovation. This case 
TABLE 3: Main features of 22@ and ID and potential opportunities.

\begin{tabular}{|c|c|c|}
\hline Urban planning & Economic reconversion & Social components \\
\hline 22@Urban Technology Park & Old industrial sites & $\begin{array}{l}\text { Associations and groups (cooperation and } \\
\text { conflicts) }\end{array}$ \\
\hline $\begin{array}{l}\text { 22@_Big Architectures and Buildings } \\
\text { (MediaTic, Torre Agbar, Cibernàrium, } \\
\text { Forum Hall }\end{array}$ & & $\begin{array}{l}\text { Voluntary Committees Representations } \\
\text { of firms }\end{array}$ \\
\hline \multirow[t]{2}{*}{$\begin{array}{l}\text { 22@International intermodal Platform } \\
\text { (La Sagrera) }\end{array}$} & & 22@breakfast \\
\hline & & $\begin{array}{l}\text { Artistic, creative, and techno } \\
\text { communities and spaces like Cibernàrium }\end{array}$ \\
\hline 22@New Universities, Departments & $\begin{array}{l}\text { Art centers in Poblenou (galleries and } \\
\text { ateliers) }\end{array}$ & \\
\hline $\begin{array}{l}\text { ID/QI-ETS, private buildings and } \\
\text { INGO }\end{array}$ & $\begin{array}{l}\text { Regeneration of ancient industrial area } \\
\text { and spaces around ETS }\end{array}$ & $\begin{array}{l}\text { Students, researches, talents, managers } \\
\text { (important mission) }\end{array}$ \\
\hline $\begin{array}{l}\text { ID/QI-Griffintown quarter; Canal } \\
\text { Lachine and old industrial areas; Bassin } \\
\text { du Nouveau Havre; Bonaventure quarter } \\
\text { and new plan of transport }\end{array}$ & $\begin{array}{l}\text { Fostering and supporting new R\&D and } \\
\text { R\&I centers (private and public) } \\
\text { Improving the role of two developing } \\
\text { clusters: (I cluster) Cité du Multimedia } \\
\text { and (II cluster) Cité du Commerce } \\
\text { Électronique }\end{array}$ & $\begin{array}{l}\text { Talents, creative and business } \\
\text { communities involve in the process of } \\
\text { regeneration. Restaurants, boutiques and } \\
\text { art galleries }\end{array}$ \\
\hline \multicolumn{3}{|c|}{ Potential transfer of elements from 22@ to ID } \\
\hline 22@BCN & $\rightarrow$ & ID@MTL \\
\hline BarcelonActiva & & - \\
\hline Development agency & & - \\
\hline $\begin{array}{l}\text { PUERTA } 22 \text { "New Spaces of Labor and } \\
\text { Market" }\end{array}$ & & - \\
\hline 7@business community & & - \\
\hline $\begin{array}{l}\text { International communities of firms and } \\
\text { business players }\end{array}$ & & - \\
\hline $\begin{array}{l}\text { Artist-run centers and galleries of } \\
\text { production }\end{array}$ & & - \\
\hline
\end{tabular}

highlights the importance of relational proximity in fostering urban development. This open neighborhood will produce socioterritorial innovations with the aim of generating a new technological district as well as a new cultural and living zone denominated "Living Lab." It will represent a districtlaboratory integrated in the ecosystem of innovation which could be supported by a synergic network of local players. It appears clearly that innovation, creativity and territory are three fundamental assets which can boost economic competitiveness and socioterritorial innovations in the Innovation District.

We have considered the innovation capacity and the business-cultural atmosphere of the overall system of firms and institutions which not only support but also increase technological development and local attractiveness. From this point of view, the 22@ represents an important pattern for the ID regeneration strategy. On the other hand, 22@ has shown to the ID district an potential urban model of development acting as a new concept of @city with the coexistence of physical and virtual urban spaces.

Indeed, on the one side, the inspiration model of 22@ can be considered as the precursor of this new urban paradigm which fosters local and diversified sectors of high-tech and multimedia production in the city's core. However, the 22@ has highlighted some difficulties in terms of connectivity and synergy between local players, difficulties that appear to be taken into account and partly overcome in the ID case. In fact a certain absence of synergy has been observed among laboratories, university departments, and firms in 22@. In addition, it is living a critical phase in terms of social participation and social innovation because local conflicts have developed in the last two years, denouncing the absence of public interests in favor of private ones. On the contrary, the territorial innovation in the ID is envisaged as an interactive process which creates linkages and networking amongst scientific institutions, firms, and local organizations. The construction of a territorial development model polarized around knowledge and innovation poles (like urban science parks and innovation clusters) represents a new approach in order to define synergic strategies as well as to foster innovation within the territory (based on relational proximity fostering knowledge exchanges). This interactive approach based on the synergies between scientific/university sectors and creative industry environments 
could represent a new model of development based on the innovation cluster and relational proximity approach. Therefore, while the 22@ appears to support a more functional perspective of technopolitan polarization based on a multi-clustered system (top-down strategy) which tends to form a hybrid model over the years, the ID appears to be planned according to a relational and synergetic perspective (bottom-up and multiple networking strategy) based on the interaction between universities and R\&I centers.

As for the lessons and guidelines useful for local players in Montreal, the positive features related to the process of agglomeration and urban regeneration in the district of Poblenou can be useful to understand, and surely the local actors will be careful about the critical and negative resulting from a lack of inclusive and participatory processes in local communities and local residents. This kind of negative impact in terms of lack of inclusive participation in Barcelona has produced much debate and has transformed the neighborhood of Poblenou into a district not experienced and not really lived in by the resident population. The ID district of Montreal is living a first phase of planning, ten years after Barcelona, and it could gain more experience and skills in managing the process of planning and governance. This is an extremely important challenge for the reconversion of ID in Montreal, but also more generally for other cities undergoing such processes of reconversion; as is seen in some of the literature, reconversion should not come at the cost of exclusion of the local population [27].

To conclude, both Barcelona and Montreal with their spatial concentration of firms and technological hubs, groups of research in laboratories and specialized universities represent two innovative urban systems. They could build new dimensions of economic and cultural performances, linking jointly innovation, territorial identities, and the knowledge economy. However, there are challenges in these processes of reconversion, as we have shown here. Firstly, Barcelona must preserve its historical tradition as a compact city as well as a multinodal and hypermodular Mediterranean hub. Second, Montreal will develop its central techno parks in order to transform deeply its urban neighborhoods and to transform inner dismissed areas into new cyberterritories of knowledge, savoir-faire, and creativity; this obviously does not go without challenges in terms of connections with the local community and common agreement on the future of the zone. In any case, it appears that the 22@ can represent an inspiration for the ID case, provided some elements are taken into account in the governance process to be more inclusive of local actors and not replicate the difficulties observed in the Barcelona case. Despite this criticism and the effects of conflictual relations at times, the elements of innovation are transforming the urban space and redefining new forms of life and social practices in Barcelona. Ten years after the planning of 22@, it represents a new urban experience in terms of accessibility, spaces of governance, and interaction between different actors, although it does need to address some issues in order to reestablish the archetype of Barcelona's model of participation.

As for the theoretical dimensions, we have explored here the theme of the functional technopole, considering it as complementary to the relational approach. Both approaches are fundamental, according to our hybrid model of clustering development for 22@ and ID, but a relational approach to proximity factors seems essential in order to ensure better urban development and better inclusion of the local population, something which has been criticized in Barcelona.

\section{Interviews}

n. 1: General Director (ÉTS); n. 2: Strategy Director (ETS); n. 3: Project Officer (Montreal City Council); n. 4: Director (CDEC-RESO); n. 5: President (Strategic Consulting Convercité); n. 6: President (Strategic Consulting Innovitech); n. 7: Project Architect (22@BCN Development Agency); n. 8: Political Adviser (22@BCN Development Agency); n. 9: Professor (UOC); n. 10: Associate Professor (UOC); n. 11: Habitant (22@-Poblenou); n. 12 Habitant (22@-Poblenou); n. 13: Strategic Multimedia and Design Consulting (22@Poblenou).

\section{Endnotes}

1. At the most basic level, the citynetwork appears as a single entity. At its most complex level, the urban phenomenon presents itself as a network that innervates progressively larger areas and configures multiscalar structures consisting of selective networks of networks. The urban entity is represented as an organism which is both a sign of local identity otherwise without distinctiveness, and an "exploded entity" in the territory, able to merge and join with other regional and local networks. The contemporary metropolis becomes emblematic of the dialectic relationship between local and global forces.

2. Yet other geographers, however, have investigated the spatial dynamics of the city, with research dedicated to the morphology of the city, describing the urban sprawl and the edge city as a progressive large-scale urbanization process. All of them seem to agree that the metropolises can be seen as nodes of a global network which establish their economic influences in regional poles through a high degree of specialization as "suburban-centralized" areas and "multidistributed centers."

3. An interesting issue in Montreal is how techno-creative sectors have become factors of local renewal, as well as strategic clusters for fostering spatial integration between enterprises and the territory on the one hand and between firms of different sectors on the other. In this manner, they achieve horizontal complementarities and specializations while emphasizing the creative vocations of the territories.

4. By the study of clustering development processes and their nature, some works have identified four stages of clusters: latent, developing, and established and transformation. 
5. In this area has been a modification of the General Metropolitan Plan (passed on 27 July 2000) in order to allow for the establishment of new activities and the combination of uses. The old zoning of industrial lands has been transformed into a new techno-creative area, known as 22@. Aims to attract activities linked to emerging sectors in manufacturing and creative industries like software production, telecommunications, multimedia, press and editing, artistic activity, and R\&D.

6. It was not until relatively recent residential operations, starting at the end of the 1980s with the removal of the over ground railway lines and the construction of the Olympic Village, that the transformation of the whole of the sea front and the completion of the Diagonal through to the sea permitted Cerda's old plan to be finally completed, with the consolidation of the Eixample grid and its main diagonal roadway, the urban backbone of the sector.

7. Barcelona City Council has created a firm denominated 22@bcn S.A., entirely founded with municipal capital, to serve as the main force behind the development of the area. This way, an independent management agency of economic local development has been created, bringing together the instruments and expertise required to manage the transformation process.

8. Business School-University of Navarra (IESE); Business School, Universitat Ramon Llull (ESADE); Escuela de Alta Direccion y Administración de Barcelona (EADA); Universidad de Barcelona (UB); Universitat Autonoma de Barcelona (UAB); Universitat Politecnica de Catalunya (UPC); Universitat Pompeu Fabra (UPF); Universitat Ramon Llull (URL); Universitat Internacional de Catalunya (UIC); Universitat Oberta de Catalunya (UOC); Institute for Advanced Architecture of Catalonia (IAAC).

9.7 7@: Barcelona Activa Local Development Agency; New Space of Labour Market "Puerta 22"; Training Center of Can Jaumandreu IL3 (UBE); Universidad Oberta de Catalunya (UOC); Barcelona Televisión; Radio Nacional de España; Communication Campus of Pompeu Fabra University; Centro de Producción Audiovisual; MediaTic building.

10. The 10 universities and departments are EMAV; IL-3; UOC; UPF Comunicación; Instituto SAE; BAU; School of Professional \& Executive Development (UPC); UPF Ciutadella; Edificio Health; B_TEC, Universidad UPC (ETSEIB+EUETIB).

11. The integration process between local players has to foster:

(i) developing an institutional integration among different local stakeholders;

(ii) increasing the level of interconnections and exchange between local players, public and private institutions and business sectors; (iii) fostering and encouraging the interconnections and the links between academic and scientific institutions and innovative firms;

(iv) encouraging the role of scientific institutions and innovation centers as important hubs for networking complementarities located in the neighborhood.

12. The relations between the ETS and the industries are very solid, and, for promoting and increasing this exchange, the ETS has created two important innovation axes of development:

(i) The Centre de l'entrepreneurship technologique (Centech), an incubator of innovative firms which has created and supported already 64 new firms.

(ii) The Centre d'expérimentation et de transfert technologique (CETT) with the aim to sustain and encourage the exchange of technologic innovations between researches and business sector.

\section{References}

[1] G. Benko and A. Lipietz, Eds., Les Régions qui Gagnent. Districts et Réseaux: Les Nouveaux Paradigmes de la Géographie Economique, PUF, Paris, France, 1992.

[2] M. E. Porter, "Clusters and the new economics of competition," Harvard Business Review, vol. 76, no. 6, pp. 77-90, 1998.

[3] G. Benko, "Technopole/technopole," in Jacques Lévy and Michel Lussault, Dictionnaire de la Géographie et de L'espace des Sociétés, Belin, Paris, France, 2003.

[4] D. G. Tremblay and S. Rousseau, "Le secteur du multimédia à Montréal peut-il être considéré comme un milieu innovateur?" Géographie, Economie et Société, vol. 7, no. 2, pp. 37-56, 2005.

[5] D. G. Tremblay and S. Rousseau, "The Montreal multimedia sector: a cluster, an "innovative milieu" or a simple collocation?" Canadian Journal of Regional Science, vol. 28, no. 2, pp. 299-327, 2006.

[6] D. G. Tremblay, J. L. Klein, and J. M. Fontan, Initiatives Locales et Développement Socioterritorial, Télé-université, Université du Québec à Montréal, Québec, Canada, 2009.

[7] R. Camagni and R. Capello, "Knowledge-based economy and knowledge creation: the Role of Space," in Growth and Innovation of Competitive Regions-The Role of Internal and External Connections, U. Fratesi and L. Senn, Eds., Springer, Berlin, Germany, 2009.

[8] P. Aydalot, "Trajectoires technologique et milieux innovateurs," in Milieux Innovateurs en Europe, pp. 347-361, GREMI, Paris, France, 1986.

[9] N. Massard and A. Torre, "Proximité géographique et innovation," in Economie de Proximités, B. Pecquer and J. B. Zimmermann, Eds., Hermès, Paris, France, 2004.

[10] R. Camagni and D. Maillat, Milieux Innovateurs: Théories et Politiques, Economica, Paris, France, 2006.

[11] D. G. Tremblay and R. Tremblay, Eds., La Compétitivité Urbaine à L'ère de la Nouvelle Économie: Enjeux et Défis, Presses de l'Université du Québec, Québec, Canada, 2006. 
[12] J.-L. Klein, D.-G. Tremblay, and J.-M. Fontan, "Systèmes locaux et réseaux productifs dans la reconversion économique: le cas de Montréal," Géographie, Economie et Société, vol. 5, no. $1,2003$.

[13] S. Conti and G. Spriano, Sistemi Urbani e Innovazione: Prospettive per l'Europa Degli Anni Novanta, vol. 1, Fondazione Giovanni Agnelli, Turin, Italy, 1990.

[14] O. Crevoisier and R. Camagni, Les Milieux Urbains: Innovation, Systèmes de Production et Ancrage, EDES, Neuchatel, Switzerland, 2000.

[15] C. Landry, The Creative City: A Toolkit for Urban Innovators, Earthscan, London, UK, 2000.

[16] M. E. Porter, "Location, clusters and company strategy," in The Oxford Handbook of Economic Geography, G. L. Clark, M. Feldman, and M. S. Gertler, Eds., Oxford University Press, Oxford, UK, 2000.

[17] S. Sassen, The Global City: New York, London, Tokyo, Princeton University Press, Princeton, NJ, USA, 1991.

[18] P. Veltz, Mondialisation, Villes et Territoires: L'économie D'archipel, Presses Universitaires de France, Paris, France, 1996.

[19] M. Storper and A. J. Scott, "Rethinking human capital, creativity and urban growth," Journal of Economic Geography, vol. 9, no. 2, pp. 147-167, 2009.

[20] M. Feldman, The Geography of Innovation, Kluwer Academic, Boston, Mass, USA, 1994.

[21] D. G. Tremblay and R. Tremblay, Eds., La Classe Créative Selon Richard Florida. Un Paradigme Urbain Plausible? Presses de l'Université du Québec, Québec, Canada, 2010.

[22] R. Florida, The Rise of the Creative Class: And How It's Transforming Work, Leisure, Community and Everyday Life, Basic Books, New York, NY, USA, 2002.

[23] R. Florida, Cities and the Creative Class, Routledge, New York, NY, USA, 2005.

[24] R. Florida, Who's Your City? How the Creative Economy is Making Where to Live the Most Important Decision of Your Life, Basic Books, New York, NY, USA, 2008.

[25] C. Landry and B. Franco, The Creative City, Demos, London, UK, 2005.

[26] E. L. Glaeser and S. Albert, The Rise of the Skilled City. Brookings-Wharton Papers on Urban Affairs, 2004.

[27] J.-L. Klein and D.-G. Tremblay, "Can we have a "creative city" without social cohesion? Some avenues of reflection," Plan Canada, vol. 52, no. 2, pp. 27-29, 2010.

[28] S. Darchen and D. G. Tremblay, "What attracts and retains knowledge workers/students: the quality of place or career opportunities? The cases of Montreal and Ottawa," Cities, vol. 27, no. 4, pp. 225-233, 2010.

[29] S. Darchen and D.-G. Tremblay, "Attracting and retaining the workforce in science and technology: the case of Montreal," in Knowledge-Based Development of Cities and Societies: An Integrated Multi-level Approach, M. Kostas, J. C. Francisco, and Y. Tan, Eds., pp. 42-58, IGI Global, Hershey, Pa, USA, 2010.

[30] A. Holbrook and D. Wolfe, Eds., Knowledge Clusters and Regional Innovation: Economic Development in Canada, Kingston: Queen's School of Policy Studies and McGill-Queen's University Press, 2002.

[31] J. N. H. Britton, D. G. Tremblay, and R. Smith, "Contrasts in clustering: the example of Canadian new media," European Planning Studies, vol. 17, no. 2, pp. 211-234, 2009.

[32] D. G. Tremblay, J. M. Fontan, J. L. Klein, and D. Bordeleau, "The development of the relational firm: the case of the Multimedia City in Montréal," in Knowledge, Clusters and
Regional Innovation: Economic Development in Canada, A. Holbrook and D. Wolfe, Eds., pp. 161-185, Mc-Gill Queens Univ. Press, Montréal, Canada, 2002.

[33] F. Carluer, "Trois cas archétypaux de polarisation spatioproductive: le district industriel, le milieu innovateur et la technopole," Revue d'Economie Régionale et Urbaine, vol. 3, pp. 567-590, 1999.

[34] M. Gertler and D. Wolfe, "Space of knowledge flows: clusters in a global context," in Proceedings of the DRUID 10th Anniversary Summer Conference on Dynamics of Industry and Innovation: Organizations, Networks and Systems, Copenhagen, Denmark, June 2005.

[35] M. Castells, The Network Society: A Cross-cultural Perspective, Edward Elgar, Londres, UK, 2004.

[36] K. Stolarick and R. Florida, "Creativity, connections and innovation: a study of linkages in the Montréal Region," Environment and Planning A, vol. 38, no. 10, pp. 1799-1817, 2006.

[37] P. Cohendet, D. Grandadam, and L. Simon, "The anatomy of the creative city," Industry and Innovation, vol. 17, no. 1, pp. 91-111, 2010.

[38] R. P. Camagni, "The concept of innovative milieu and its relevance for public policies in European lagging regions," Papers in Regional Science, vol. 74, no. 4, pp. 317-340, 1995.

[39] Ville de Montréal, Montréal, Ville de Savoir. Rapport du Comité Conseil Montréal Ville de Savoir, Ville de Montréal, 2003.

[40] Ville de Montréal, Reussir@Montréal, Stratéges de Développement Economique 2005-2010 de la Ville de Montréal, Ville de Montréal, 2005.

[41] A. J. Scott and M. Storper, "Innovation and space: a critical review of the literature," Regional Studies, vol. 39, p. 789, 2003.

[42] P. L. Sacco and G. Ferilli, Il Distretto Culturale Evoluto Nell'economia Post Industriale, DADI, Università IUAV WP, Venice, Italy, 2006.

[43] M. Castells and P. Hall, Technopoles of the World: the Making of Twenty-First Century Industrial Complexes, Routledge, London, Minn, USA, 1994.

[44] M. E. Porter, "The competitive advantage of the inner city," Harvard Business Review, vol. 73, no. 3, pp. 55-71, 1995.

[45] OECD, Global Knowledge Flows and Economic Development, OECD, Paris, France, 2004.

[46] D. Harvey, The Condition of Postmodernity: An Enquiry into the Origins of Cultural Change, Blackwell, Cambridge, UK, 1990.

[47] ÉTS and McGill, Quartier de l'Innovation de Montréal. État de Situation et Orientations pour sa Mise en Oeuvre, ÉTS and McGill, 2011.

[48] A. J. Scott, "Creative cities: conceptual issues and policy questions," Journal of Urban Affairs, vol. 28, no. 1, pp. 1-17, 2006.

[49] G. Evans, "Creative cities, creative spaces and urban policy," Urban Studies, vol. 46, no. 5-6, pp. 1003-1040, 2009.

[50] G. Becattini, "Italian districts: problems and perspectives," International Studies of Management and Organization, vol. 21, no. 1, pp. 83-90, 1991.

[51] J. M. Fontan, J. L. Klein, and D. G. Tremblay, Innovation Socioterritoriale et Reconversion Economique: Le Cas de Montréal, L'Harmattan, Paris, France, 2005.

[52] S. Bagwell, "Creative cluster and city growth," Creative Industries Journal, vol. 1, no. 1, pp. 31-46, 2008.

[53] L. van den Berg, Urban Systems in a Dynamic Society, Gower Publishing Company, Aldershot, UK, 1987.

[54] A. Oliva, El Districte d'Activitat 22@bcn, (Model Barcelona), Quaderns de Gestiò, 15 Aula Barcelona, Universitat de Barcelona, 2003. 
[55] Diputacio' de Barcelona, Cultura en Xarxa. La Politica Cultural de la Diputacio' de Barcelona, Diputacio de Barcelona, Barcelona, Spain, 2000.

[56] Ajuntament de Barcelona, El Futur Desenvolupament de les Industries de Cotinguts d'Informacio' de la Ciutat de Barcelona, Ajuntament de Barcelona, Barcelona, Spain, 2000.

[57] R. M. Delgado, La Ciudad Mentirosa. Fraude y Miseria del Modelo Barcelona, La Piqueta, Madrid, Spain, 2007.

[58] Barcelona Activa, Report on Activities, Ajuntament de Barcelona, 2008.

[59] K. Fundacio, Ciudades Creativas, vol. 1, Kreanta, Barcelona, Spain, 2010.

[60] N. Cattan, Cities and Networks in Europe. A Critical Approach of Polycentrism, John Libbey Eurotext, Paris, France, 2007.

[61] DDAA, La Barcelona Rebelde. Guia de una Ciudad Silenciada, Octaedro, Barcelona, Spain, 2003.

[62] DDAA, La Ciutat Vella: Un Passat Amb Futur, Ajuntament de Barcelona, Barcelona, Spain, 2003.

[63] F. Mascarell, Barcelona y la Modernidad. La Ciudad Como Proyecto de Cultura, Editorial Gedisa, Barcelona, Spain, 2008.

[64] J. Borja, Luces y Sombras del Urbanismo de Barcelona, UOC, Barcelona, Spain, 2010.

[65] Barcelona Activa, Report on Activities, Ajuntament de Barcelona, 2009.

[66] Ajuntament de Barcelona, Barcelona: Ciutat del Coneixement, Barcelona Metropolis Mediterranea, n. 1, Barcelona, Spain, 2000.

[67] T. Pilati and D.-G. Tremblay, "Le développement socioéconomique de Montréal: la cité créative et la carriere artistique comme facteurs d'attraction?" Canadian Journal of Regional Science, vol. 30, no. 3, pp. 475-495, 2008.

[68] Ville de Montréal, Montréal, Ville Apprenante, de Savoir et d'Innovation, Ville de Montréal, 2007.

[69] G. Benko and A. Lipietz, Eds., La Richesse des Regions, PUF, Paris, France, 2000.

[70] Convercité Development Agency, Plan Directeur de Développement des Actifs Immobiliers et Fonciers non Développés de l'ETS, Convercité D.A., 2009.

[71] M. Lessard, "l'ÉTS mise sur un quartier de l'Innovation," Formes, vol. 6, no. 3, 2010. 


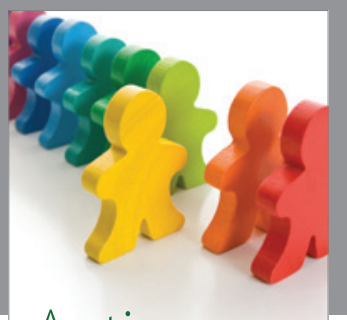

Autism

Research and Treatment
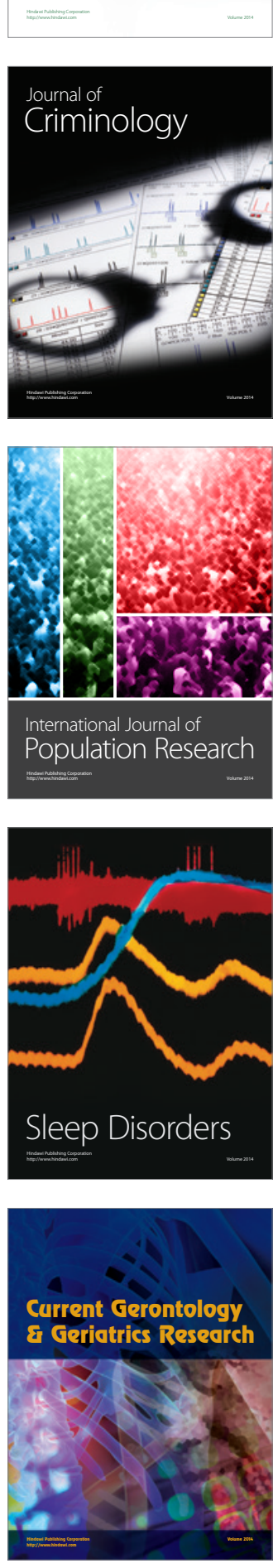
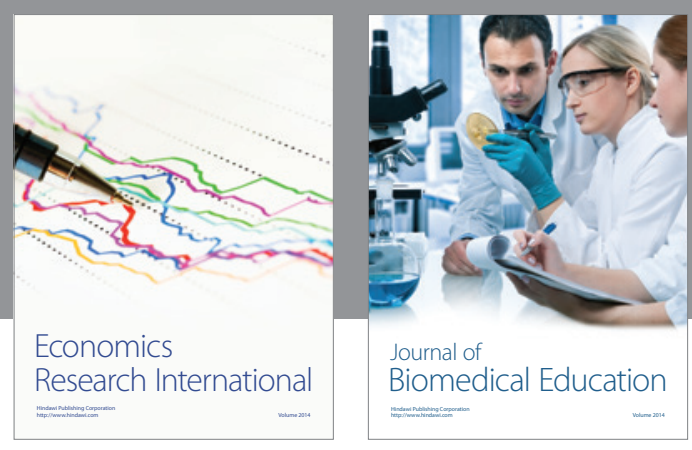

Journal of

Biomedical Education

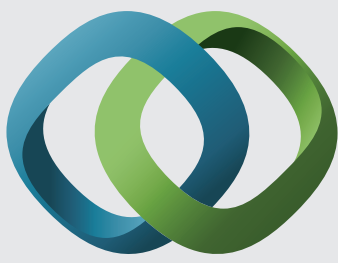

\section{Hindawi}

Submit your manuscripts at

http://www.hindawi.com
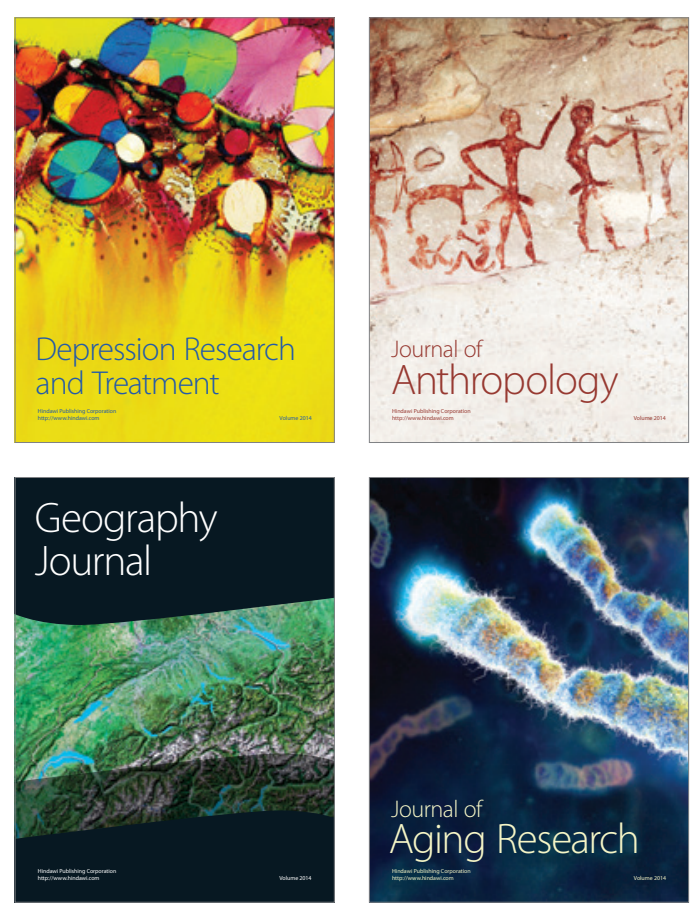

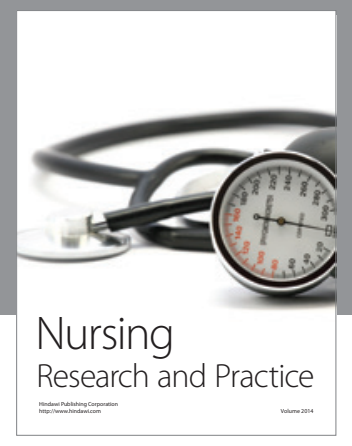

Nursing

Research and Practice

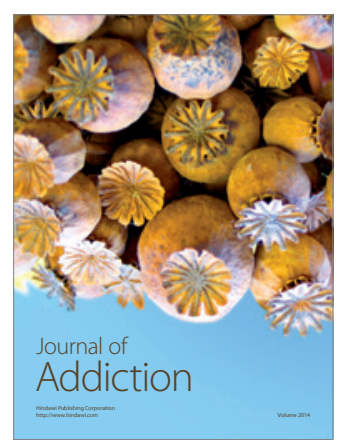

Child Development

Research

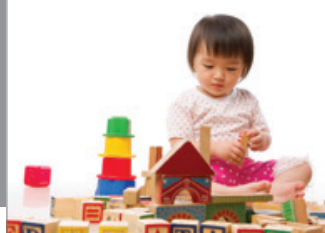

迥
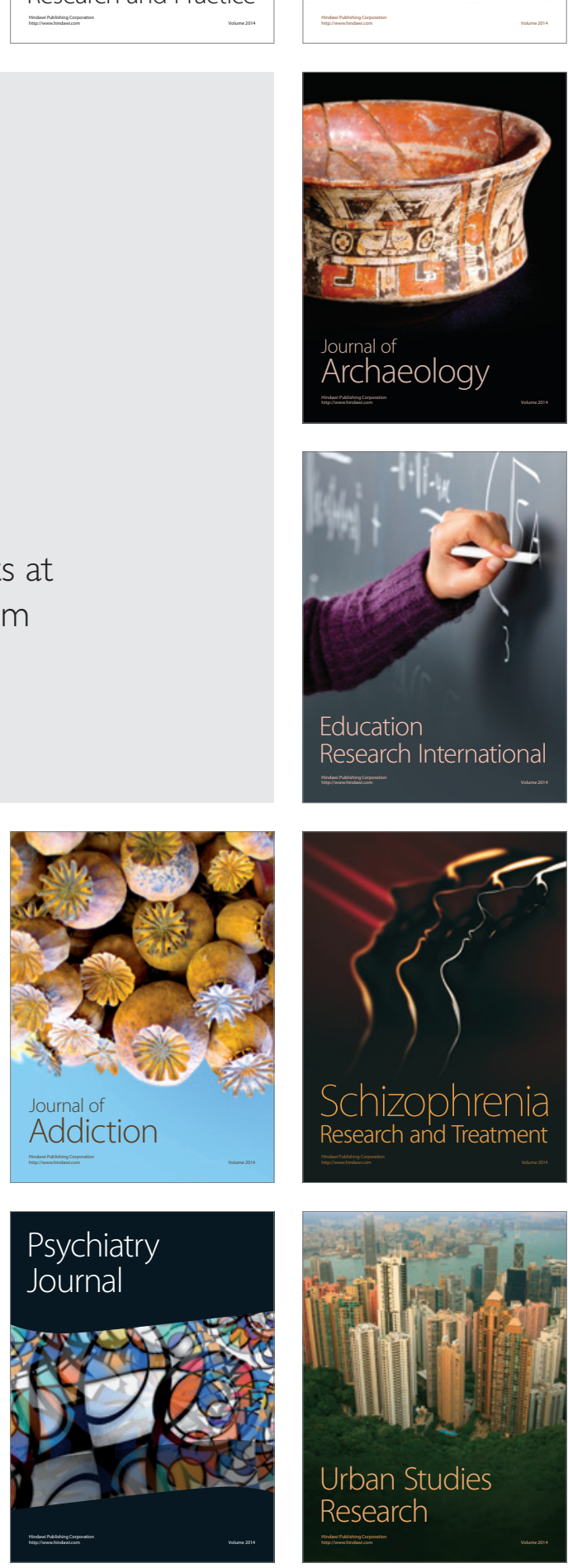